\title{
Article
}

\section{Book Review: Alan McKinlay and Philip Taylor Foucault, Governmentality, and Organization: Inside the Factory of the Future}

Martin, Douglas

Available at http://clok.uclan.ac.uk/14714/

Martin, Douglas ORCID: 0000-0003-4056-5869 (2016) Book Review: Alan McKinlay and Philip Taylor Foucault, Governmentality, and Organization: Inside the Factory of the Future. Work Employment and Society .

It is advisable to refer to the publisher's version if you intend to cite from the work. http://dx.doi.org/10.1177/0950017016643483

For more information about UCLan's research in this area go to http://www.uclan.ac.uk/researchgroups/ and search for < name of research Group>.

For information about Research generally at UCLan please go to http://www.uclan.ac.uk/research/

All outputs in CLoK are protected by Intellectual Property Rights law, including Copyright law. Copyright, IPR and Moral Rights for the works on this site are retained by the individual authors and/or other copyright owners. Terms and conditions for use of this material are defined in the policies page.

\section{CLoK}

Central Lancashire online Knowledge www.clok.uclan.ac.uk

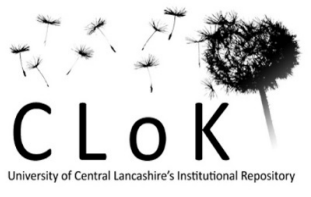


Alan McKinlay and Philip Taylor

Foucault, Governmentality, and Organization: Inside the Factory of the Future

Abingdon: Routledge, 2014, £85.00, hbk, (ISBN: 9780415749053), 184 pp.

Reviewed by Douglas Martin, University of Central Lancashire, UK

This book by McKinlay and Taylor, the latest in the Routledge Series on Employment Research, offers a further opportunity to examine the lives of workers in the contemporary workplace in the labour process tradition. The book examines the Motorola electronics factory in East Kilbride and the impact on the workforce from the opening of the plant in 1969 to its closure in 2001. The authors use Foucault's theory of governmentality as a frame through which to examine organisational restructuring.

The opening chapter provides an extensive overview of the main themes of the book suggesting governmentality is Foucault's 'most productive concept' (page 2). The authors, in addressing both the utility of the concept and its potential limitations, discuss the extent to which technologies have the capacity to create employees better able to self-discipline where the aim of management is seemingly to manage without managers. The significance of managerial discourse is not simply rhetoric. There are material consequences insofar as systems of governmentality have repercussions on management's manipulation of the labour process.

Chapter 2 provides the context to the establishment of the factory, while Chapter 3 examines the philosophy that framed the factory's development. Motorola's corporate values of humanism and individualism were improvised in the local setting to create the 'factory of the future' of the title. The success of the factory, predicated on the use of self-directed teams, was an extension of the capacity given to local management to develop a technology of team working specific to this new site. This reflected a degree of decentralisation allied to local management's attempts to counteract adversarial staff relations witnessed elsewhere. Chapter 4 explores the ambiguity of self-directed working. By examining different groups of workers, for example, the original cohort of employees with newer recruits, the chapter demonstrates the tensions within the teams. The philosophy of self-directed teams became increasingly incompatible with its organisational demands.

Chapter 5 provides an interesting application of Foucault's conceptualisation of confession to the contemporary factory. The focus is on peer review and the ways in which self-surveillance sustains the 'conduct of conduct'. Contrary to what Foucault suggests, the peer review system adopted by Motorola did not generate the forms of indirect control anticipated by management. It failed for the most part to generate self-empowering teams. The ritual of peer review did not cause workers to confess their flaws to others, but was subject to employees' reluctance to open up to others to protect their autonomy as individuals. The final chapter discusses how the insertion of a layer of middle managers and the recruitment of temporary workers contributed to the further demise of selfempowering teams hastening the end of the 'factory of the future'. This final chapter contextualises how attempts to build a 'pure model' of team-working floundered under pressures from the global firm. A short coda helpfully draws the key themes together rescuing Foucault from his oft-used caricatured version highlighting how his concepts of power and discipline can be used to evaluate how individual behaviours at work are monitored. The authors argue that the durability and logic of surveillant systems are key factors in evaluating discipline in the contemporary factory. By adding this notion of durability, the authors lay bare the incompleteness of any surveillant system. With the 
labour process tradition highlighting the capacity of the workforce to resist management, this idea of durability is a useful one in analysing why surveillance fails.

This book provides important insights into the ethos of peer review and team working from the perspectives of the workforce, but at the same time gives due weight to the consequences of managerial rhetoric and actions in the specific context of the firm. Using the perspectives of different groups of workers in the factory, the authors highlight the failings and gradual breakdown of the Motorola experiment. The subtitle to the book, Inside the Factory of the Future, is perhaps somewhat of a misnomer when much of the fieldwork was undertaken in the mid-1990s. How governmentality might apply to workplaces in the current era of lean production systems and 360 degree feedback would be a project worth exploring. Some comment would have been useful in this respect. That aside, this book provides a very useful evaluation of the rationale and ethos of management systems of self-surveillance. The authors raise important issues around the incompleteness of governmental relations. Not least, they ask why systems predicated on worker self-management fail even in circumstances where local management retain a belief in manager-less systems. This study in using the concept of governmentality illustrates how surveillant systems not only fail to generate selfdiscipline, but also how control of the labour process within teams is subject to pressures from outwith the local setting and from within. With the closure of the Motorola factory, the book is also a sad and timely reminder that all workforces are subject to forces from beyond the factory walls irrespective of how governmentality operates on the shop floor. 